\title{
Effects of the 1978 Land Use Act on Sustainable Mining and Petroleum Industries in Nigeria
}

\author{
Opafunso $\mathrm{ZO}^{1 *}$, Bruno-Imokhai $\mathrm{JO}^{2}$ and Akinbosade $\mathrm{BA}^{3}$ \\ ${ }^{1,2}$ Federal University of Technology Akure, Akure, Nigeria \\ ${ }^{3}$ Ministry of Local Government, Akure, Akure, Nigeria
}

\begin{abstract}
The study examined and appraised the effects of the 1978 land use act on sustainable mining and petroleum industries in Nigeria. It identified the vital land policies that guaranteed smooth land acquisition, operation and management in these industries. The study attempted to find answers to the research questions by using a survey design and a precise sampling technique to collect data from 200 respondents with the aid of a 53 item questionnaire. Data for this study was analyzed using Statistical Package for Social Science (SPSS) and the chi-square $\left(x^{2}\right)$ was used to test the two hypotheses posed for the research at a $5 \%$ significant level. The findings revealed that the 1978 land use act has enabled the government meet the land needs of Nigerian, especially for developmental need in mining, gas and petroleum industries. This was shown from the data analyzed through the question on whether the land use act has not endangered rapid urban and rural infrastructural developments where $43(21.5 \%)$ strongly agreed, $88(44 \%)$ agreed, $22(11 \%)$ disagreed and $23(11.5 \%)$ strongly disagreed to this. The study recommended the right sense of justice and fairness to be played by the government in terms of land use administration to greatly reduce further allegations and critics by Nigerians in terms of this act enriching government officers.
\end{abstract}

Keywords: Compensation; Petroleum; Mining; Sustenance; Constitution; Statutory; Land

\section{Introduction}

The significance of this natural asset, land to man on earth through all ages can hardly be overstressed. Land, though represents only about one-third of the earth's surface, provides a platform on which man's activities ranging from shelter, food, industrial activities and movement are based. It is however ironical that while the world population rises, the land in supply appears to be declining. Nigeria, having a land mass of 923,768 sqkm and an increasing population of greater than 150 million people, therefore, the possession of land is guarded against. Wars are fought, territories conquered, various conflicts in regions to affirm and realm the ownership of land. These activities hindered the smooth development for the need of a stable mineral and petroleum industry in the country. The rift between Nigeria and Cameroon over Bakassi Peninsula, wars between Ife and Modakeke and that between Erinle and Offa attest to the above claim [1]. For available land to be equitably managed among the people and promote maximal use of it by prospective resource owners (mining, oil and gas), there is need for a worthy land policy to be in place for effective control and management of land in order to witness the desired development in Nigeria.

Prior to $29^{\text {th }}$ March, 1978 when the Land Use Act was enacted, there were land laws which governed land tenure systems in Nigeria. These laws were in use in the country and were later found to be substandard because despite their existence, the problems of land tenure continued in Nigeria. One major problem was the difficulty in obtaining land by the government in major urban centers for national development because of land speculations, racketeering and high cost of compensation usually demanded by the land owners whenever government acquired land to execute its projects [2]. Against this background, the Federal Government in a deliberate effort to unify land tenure, streamline and simplify ownership of land in Nigeria, set up the Land Use Panel in 1977 with certain terms of reference [3]. The references were considered and adopted by the government which promulgated the Land Use Act, 1978. This study is carried out diligently to evaluate it in the light of its creditable objectives to see whether land is better managed and controlled, pointing out its effect, for sustainable use in mining, oil and gas industries under the Act.

Prior to the enactment of the Land Use Act in 1978, there were three main sources of land law: Customary Law (varied from custom to custom), English received law (which comprises of the common law, doctrine of equity and statutes of General application), and local legislation [4]. The Parliament of the then northern Nigeria passed the Land Tenure Law in 1962, which governed all interest affecting land. In the then Southern Nigeria, however, customary system of land tenure governed land interest and land was owned by communities, families and individuals in freehold [5]. Land was acquired either by inheritance, first settlement, conveyance, gift, outright purchase or long possession, as such, causing conflicts and violence in terms of ownership.

The Land Use Decree was promulgated on 29 March, 1978 following the recommendations of a minority report of a panel appointed by the Federal Military Government of the time to advice on future land policy [6]. The land use act distinguishes throughout between urban and non-urban (hereafter 'rural') land. In urban areas (to be so designated by the Governor of a state), land was to come under the control and management of the Governor, while in rural areas it was to fall under the appropriate local government [7]. The Decree envisaged that 'rights of occupancy', which would appear to replace all previous forms of title, would form the basis upon which land was to be held [8]. These rights were of two kinds: statutory and customary [7]. Statutory rights of occupancy were to be granted by the Governor and related

*Corresponding author: Opafunso ZO, Federal University of Technology Akure, Akure, Nigeria, Tel: +23403350500; E-mail: zopafuso@yahoo.com

Received February 02, 2015; Accepted June 30, 2015; Published July 06, 2015

Citation: Opafunso ZO, Bruno-Imokhai JO, Akinbosade BA (2015) Effects of the 1978 Land Use Act on Sustainable Mining and Petroleum Industries in Nigeria. Arts Social Sci J 6: 106. doi:10.4172/2151-6200.1000106

Copyright: (c) 2015 Opafunso ZO, et al. This is an open-access article distributed under the terms of the Creative Commons Attribution License, which permits unrestricted use, distribution, and reproduction in any medium, provided the original author and source are credited. 
principally to urban areas. In contrast, a customary right of occupancy, according to the Decree, 'means the right of a person or community lawfully using or occupying land in accordance with customary law and includes a customary right of occupancy granted by Local Government under this Decree.' Local governments were empowered to grant customary rights of occupancy to any person or organization (for mining, oil and gas), residential and other purposes with the proviso that grants of land for agricultural or grazing purposes should not exceed 500 or 5000 hectares respectively without the consent of the State Governor [9]. With the minor exception of land subject to Federal or State claims, the Decree also empowered the local government to 'enter upon, use and occupy for public purposes any land within the area of its jurisdiction' and to revoke any customary right of occupancy on any such land [6]. Under the Land Use Act 1978, all land in Nigeria is vested in the government. Nigeria operates two systems of land tenure. They are; customary and non-customary (statutory) system of land tenure. Customary land tenure system is a system of landholding indigenous to the people, and Local governments may grant customary rights of occupancy to land in any non-urban area to any person or organization for agricultural, residential, and other purposes, including mining, oil and gas extraction [10]. In the statutory tenure system, individuals and entities can obtain a statutory right of occupancy for urban and non-urban land [10]. Statutory occupancy rights are granted for a definite term, which is set forth in the certificate. The objectives of this study was to investigate the effects of the 1978 land use act on sustainable mining and petroleum industries in Nigeria and assess the efficiency of the management of land under the land use act in a way to determine the effects of it to sustainable solid mineral industries in Nigeria. Also, the study evaluated the competence of the 1978 land use act as it affects the performance of the Nigerian petroleum industries.

\section{Theoretical Framework}

Sustenance in mining and petroleum industries of Nigeria through the land use act is built upon the Entitlement theory by Nozick [11] and the John Locke's theory of property. These theories were suitable for this study because it analyzes the effects (effectiveness and complexities) and need of a stable 1978 land use act for sustainable mining and petroleum industries in Nigeria. The Nozickian's entitlement theory, [11] supports human justice for compensation to be paid to land owners by the government for their infrastructural use. Therefore, to eliminate conflict arising from land issues, this theory pointed out the need for negotiations to be made for acquisition and compensation to be made. Lastly, the John Locke's theory [12], of property enables growth and development in a particular nation because its principle allows ownership of land resources due to the exertion of labor (physical and mental) for production of a suitable output.

\section{Methodology}

Nigeria as a country in Africa is bounded on longitude $8^{\circ} 00^{\circ} 00 \mathrm{E}$ and latitude $10^{\circ} 00^{\circ} 00 \mathrm{~N}$. She has a land mass of 923,768 square kilometers with various ethnic groups having different customs and traditions of which affects the tenure system of the country at large. The structure of this research was centered on the questionnaires administered; that is, a 53-item structured questionnaire. The questionnaire consisted of five sections, A, B, C, D and E. Section A was based on the respondent's bio-data, section $\mathrm{B}$ was based on the general issues about land use in Nigeria, Section C was based on the effects of the 1978 land use act in the solid mineral industries, section $\mathrm{D}$ was based on the effects of the 1978 land use act in petroleum industries and section $\mathrm{E}$ was based on the proposed amendments on the 1978 land use act. Copies of the questionnaires were administered to Legal Practioners (Akure, Ondo state), Lecturers (Federal University of Technology, Akure, Obafemi Awolowo University, Ife, University of Benin and University of Ibadan), Technocrats (kogi, Akure) and Civil Servants (Akure, Benin). The research population comprised of experts in the field of the above study which were estimated to be 240 . This population size was distributed into fifty (50) technocrats, eighty (80) lecturers, sixty (60) legal practitioners and fifty (50) civil servants. Out of the 240 questionnaires administered, 205 responded to the questionnaires at $85.4 \%$. Five of the 205 were invalid leaving only 200 $(83.3 \%)$ questionnaires for analysis. The research data were collected from the respondents using the questionnaires administered.

The questionnaires collected through the field survey were collated, sorted-out, coded in accordance to Statistical package for social science (SPSS) package numeric coding format. Data coded were entered into MS EXCEL format and validated before copied to SPSS Version 15.0. Again, descriptive statistics was used to analyze the data for this study. The hypotheses set for the study were treated using the chi-square at a $5 \%$ significant level.

\section{Research Questions}

The following were the research questions posed to guide this study.

1) Has the Land use act enabled the Federal, State and Local government meet the land needs of Nigerians for development use?

2) Does the Land use act contribute to family feud and conflicts in the administration of land than prior to its enactment?

3) How does the exposure of national land, which represents an integral part of our sovereignty, to the whim of civilian or military governors constitute a hindrance to the growth and development of Nigerian economy?

4) To what extent has the Land use act presented inequality in land ownership and increasing landlessness among the poorer traditional land owners?

\section{Statement of Hypothesis}

\section{Hypothesis I}

$\mathrm{H}_{0}$ : Making the land use act to be part of the constitution does not make its amendment very difficult and therefore should not remain a statutory enactment outside the constitution.

$\mathrm{H}_{1}$ : Making the land use act to be part of the constitution makes its amendment very difficult and therefore should remain a statutory enactment outside the constitution.

\section{Hypothesis II}

$\mathrm{H}_{0}$ : Land use act abrogation of the right of ownership of land by Nigerians is inconsistent with democratic practices and free market economic systems on sustainable mining and petroleum industries.

$\mathrm{H}_{1}$ : Land use act abrogation of the right of ownership of land by Nigerians is consistent with democratic practices and free market economic systems on sustainable mining and petroleum industries.

\section{Data Presentation and Analysis}

In order to answer the research questions posed for this study, data generated from the field were analyzed. The respondent's biodata was first analyzed for validity purposes. From the 53-item 
Citation: Opafunso ZO, Bruno-Imokhai JO, Akinbosade BA (2015) Effects of the 1978 Land Use Act on Sustainable Mining and Petroleum Industries in Nigeria. Arts Social Sci J 6: 106. doi:10.4172/2151-6200.1000106

Page 3 of 5

structured questionnaire, it was discovered that out of the 240 copies of questionnaire administered, 205 (85.4\%) copies were returned, 5 out of these number were invalid leaving the researcher with only 200 copies (83.3\%). Out of the returned copies, 147 (73.5\%) of respondents were male, while the remaining $53(26.5 \%)$ were female. In addition, $33(16.5 \%)$ of the respondents had their ages in range of $20-25$ years, $78(39.0 \%)$ had their ages in range of $26-35$ years, 33 (16.5\%) had their ages in range of 36-45 years and $56(28 \%)$ had their ages above 46 years. Also, 3 (1.5\%) were secondary school certificate holders, 89 (44.5\%) university graduates, $69(34.5 \%)$ had their master degrees and $36(18 \%)$ were Ph.D. holders. Finally, a larger percentage of the population were married 153 (76.5\%) and 47 (23.5\%) were single.

\section{Results and discussions of findings}

The results of the study were presented in line with the hypotheses formulated.

Enhancing development through the 1978 land use act: Answer to research question 1 (has the land use act enabled the Federal, State and Local governments to meet the land needs of Nigerians for development use?), analyzed with question 26 of the questionnaire; has the land use act endangered rapid urban and rural infrastructural development? (Table 1 and Figure 1).

Interpretation of opinion of respondents on enhancing development through the 1978 land use act: 25 (12.5\%) of the respondents strongly agreed to this notion, $24(12 \%)$ agreed to it, the larger percentage of 90 (45\%) disagreed to this, 45 (22.5\%) strongly disagreed and $16(8.0 \%)$ had no opinion to this notion. The result revealed that the enactment of the 1978 land use act has aided in smooth infrastructural development by the government of the country. This is in line with the labor theory of property by John Locke, (1688) which holds that property originally comes about by the exertion of labor upon natural resources to achieve meaningful production to the citizens in a community. Therefore, due to ease in accessing land for mining and petroleum operations, rapt growth and development is possible in the country.

\begin{tabular}{|l|c|c|c|c|}
\hline Response & Frequency & Percent (\%) & $\begin{array}{c}\text { Valid percent } \\
\text { (\%) }\end{array}$ & $\begin{array}{c}\text { Cumulative } \\
\text { percent (\%) }\end{array}$ \\
\hline Strongly Agree & 25 & 12.5 & 12.5 & 12.5 \\
\hline Agree & 24 & 12.0 & 12.0 & 24.5 \\
\hline Disagree & 90 & 45.0 & 45.0 & 69.5 \\
\hline Strongly Disagree & 45 & 22.5 & 22.5 & 92.0 \\
\hline No Opinion & 16 & 8.0 & 8.0 & 100.0 \\
\hline Total & $\mathbf{2 0 0}$ & $\mathbf{1 0 0 . 0}$ & $\mathbf{1 0 0 . 0}$ & \\
\hline
\end{tabular}

Source: Field Survey, September, 2014

Table 1: Percentage of Respondence on How the Land Use Act has Endangered Rapid Urban and Rural Infrastructural Development.

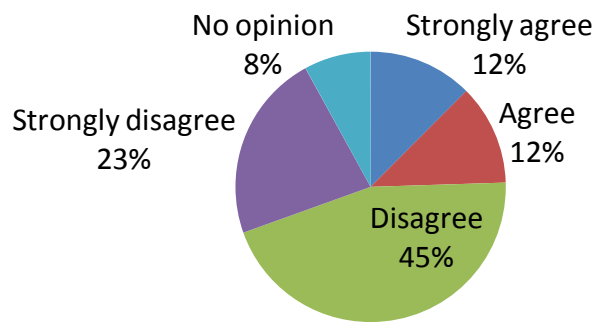

Figure 1: A Pie Chart showing the Percentage of Respondence on How the Land Use Act has Endangered Rapid Urban and Rural Infrastructural Development.

\begin{tabular}{|l|c|c|c|c|}
\hline Response & Frequency & Percent (\%) & $\begin{array}{c}\text { Valid percent } \\
\text { (\%) }\end{array}$ & $\begin{array}{c}\text { Cumulative } \\
\text { percent (\%) }\end{array}$ \\
\hline Strongly Agree & 45 & 22.5 & 22.5 & 22.5 \\
\hline Agree & 69 & 34.5 & 34.5 & 57.0 \\
\hline Disagree & 48 & 24.0 & 24.0 & 81.0 \\
\hline Strongly Disagree & 17 & 8.5 & 8.5 & 89.5 \\
\hline No Opinion & 21 & 10.5 & 10.5 & 100.0 \\
\hline Total & $\mathbf{2 0 0}$ & $\mathbf{1 0 0 . 0}$ & $\mathbf{1 0 0 . 0}$ & \\
\hline
\end{tabular}

Source: Field Survey, September, 2014

Table 2: Percentage of Respondence on How the Act as Aided Smooth Acquiring of Land for Use; Eliminating Conflicts and Troubles from Land Dwellers.

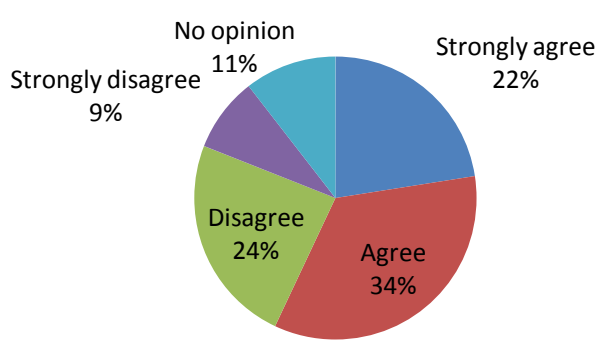

Figure 2: A Pie Chart showing the Percentage of Respondence on How the Act as Aided Smooth Acquiring of Land for Use; Eliminating Conflicts and Troubles from Land Dwellers.

Land acquisition and troubles addressed in the land use act: Reaction to research question 2 (does the land use act contribute to family feud and conflicts in the administration of land than prior its enactment?) analyzed on question 24 , (has the act aided smooth acquiring of land for use; eliminating conflicts and trouble from land dwellers (Table 2 and Figure 2).

Interpretation of opinion of respondents on land acquisition and troubles addressed in the land use act: Table 2 Shows that 45 (22.5\%) strongly agreed, 69 (34.5\%) agreed to it, 48 (24\%) disagreed to this statement, a total number of $17(8.5 \%)$ strongly disagreed to this and $21(10.5 \%)$ had no opinion to this view. The 1978 land use act has aided in reducing conflicts and crisis in terms of land possession in the country. Udoekanem suggested that in remediating environmental damage caused by mining and petroleum operations in Nigeria, the payment of adequate compensation to the land owners of environmental assets affected by pollution is very necessary. In contrast to this, the respondent's view of the act not addressing this is because of the right compensation wasn't paid to dwellers in those communities.

Contribution of the land use act to the economy of the country: Reaction to research question 3 (does the exposure of national land, which represent an integral part of our sovereignty, to the whim of civilian or military governors constitute a hindrance to the growth and development of Nigerian economy), analyzed on question 28 of the questionnaire (waiting for and obtaining governor's consent as stated in the land use act has hindered economic growth in Nigeria) (Table 3 and Figure 3).

Interpretation of opinion of respondents on contribution of the land use act to the economy of the country: This finding revealed that $26(13.0 \%)$ of the respondents strongly agreed to this statement posed, $46(23.0 \%)$ agreed to this statement, the greater part of the respondents $82(41.0 \%)$ disagreed to this, $27(13.5 \%)$ strongly disagreed and 19 (9.5\%) had no opinion to the statement. The governor of any state of the federation as aided in the economic boost of the country through the land use act as revealed in Figure 3. 


\begin{tabular}{|l|c|c|c|c|}
\hline Response & Frequency & Percent (\%) & $\begin{array}{c}\text { Valid percent } \\
\text { (\%) }\end{array}$ & $\begin{array}{c}\text { Cumulative } \\
\text { percent (\%) }\end{array}$ \\
\hline Strongly Agree & 26 & 13.0 & 13.0 & 13.0 \\
\hline Agree & 46 & 23.0 & 23.0 & 36.0 \\
\hline Disagree & 82 & 41.0 & 41.0 & 77.0 \\
\hline Strongly Disagree & 27 & 13.5 & 13.5 & 90.5 \\
\hline No Opinion & 19 & 9.5 & 9.5 & 100.0 \\
\hline Total & $\mathbf{2 0 0}$ & $\mathbf{1 0 0 . 0}$ & $\mathbf{1 0 0 . 0}$ & \\
\hline
\end{tabular}

Source: Field Survey, September, 2014

Table 3: Percentage of Respondence on How Waiting for and Obtaining Governor's Consent as Stated in the Land Use Act has Hindered Economic Growth in Nigeria.

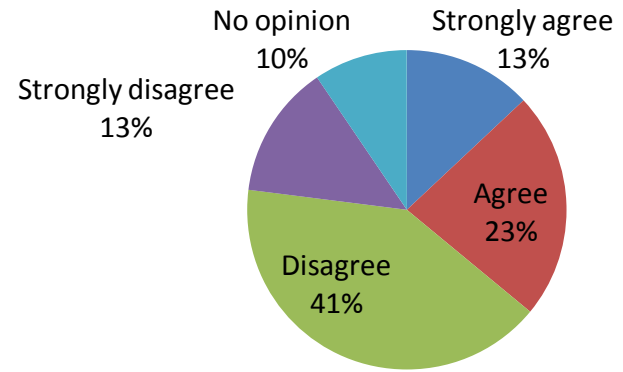

Figure 3: A Pie Chart showing the Percentage of Respondence on How Waiting for and Obtaining Governor's Consent as stated in the Land Use Act has Hindered Economic Growth in Nigeria.

\begin{tabular}{|l|c|c|c|c|}
\hline Response & Frequency & Percent (\%) & $\begin{array}{c}\text { Valid percent } \\
\text { (\%) }\end{array}$ & $\begin{array}{c}\text { Cumulative } \\
\text { percent (\%) }\end{array}$ \\
\hline Strongly Agree & 22 & 11.0 & 11.0 & 11.0 \\
\hline Agree & 34 & 17.0 & 17.0 & 28.0 \\
\hline Disagree & 79 & 39.5 & 39.5 & 67.5 \\
\hline Strongly Disagree & 38 & 19.0 & 19.0 & 86.5 \\
\hline No Opinion & 27 & 13.5 & 13.5 & 100.0 \\
\hline Total & $\mathbf{2 0 0}$ & $\mathbf{1 0 0 . 0}$ & $\mathbf{1 0 0 . 0}$ & \\
\hline
\end{tabular}

Source: Field Survey, September, 2014

Table 4: Percentage of Respondence on if the Land Use Act Represents Compulsory Acquisition of Citizen Property or Naturalization of Land by the Ruling Elite without Compensation to Land Owners.

Justice in terms of compensation paid by the government as stated in the act: Response to research question 4(to what extent has the land use act presented inequality in land ownership and increasing landlessness among the poorer traditional land owners?), analyzed on question 44 of the questionnaire (land use act represent compulsory acquisition of citizen property or naturalization of land by the ruling elite without commensurate compensation to the original land owners? (Table 4 and Figure 4).

Interpretation of opinion of respondents on justice in terms of compensation paid by the government as stated in the act: A small percentage of respondents strongly agreed to this $22(11.0 \%), 34$ (17.0\%) of the respondents agreed to this notion, 79 (39.5\%) disagreed to this view, 38 (19\%) strongly disagreed to this and $27(13.5 \%)$ had no opinion on this statement. From the research analysis, one basic policy that attributes this act is the payment of the compensation to dwellers if land is to be used by government for developmental and other purposes. The principle of rectification of injustice described how to deal with landholdings that are unjustly acquired or transferred, whether and how many victims can be compensated or injustice done by a government in a particular state (Nozick). Therefore, from the respondents view on this statement, the government still continues to pay this to dwellers to foster peace and stability in petroleum and mining areas of the country.

At 5\% (0.05) level of significance, the Pearson's chi square value was 36.956 as determined using the SPSS program. In the test for significance using the two sided, the chi square value was 0.058 . Using the statistical package for social science program, the hypothesis $\left(\mathrm{H}_{1}\right)$ which states that making land use act to be part of the constitution make its amendment very difficult and should remain statutory enactment outside the constitution was rejected and the alternative null hypothesis $\left(\mathrm{H}_{0}\right)$ accepted. In essence, incorporating the land use act in the constitution does not make amendment difficult and should not remain statutory enactment outside the constitution.

At 5\% (0.05) level of significance, the Pearson's chi square value was 35.471 as determined using the SPSS program. In the test for significance using the two sided, the chi square value was 0.080 . The analysis showed that the null hypothesis $\left(\mathrm{H}_{0}\right)$ which states the land use act abrogation of the right of ownership of land by Nigerians is inconsistent with democratic practices and free market economic systems on sustainable mining and petroleum industries was accepted and the alternative hypothesis $\left(\mathrm{H}_{1}\right)$ rejected. This means, abolishing the land use act on the right of ownership by Nigerians, consistent with democratic practices and free market economic system on sustainable mining and petroleum industries is insignificant to this view.

\section{Conclusion}

The land use act as contributed immensely to the development of the country through the provision of infrastructures and allowing private individuals set up mining and petroleum industries in the country. This is solely important in fostering economic growth in Nigeria. However, a joint sum of $22.5 \%$ of the respondents revealed that this development is on a slow rate because of the corrupt practices of some government officials in regards to this act. The enactment of the 1978 land use act has cheered peace in communities in terms of land acquisition and ownership of land. This is revealed in the analysis where a cumulative $57 \%$ of the respondents as against $32.5 \%$ accepted the view. Therefore, this has enhanced mining and petroleum industries in those areas. Again, the land use act was legislated for the purpose of justice and fairness in terms of land use in the country. As such, the issue of increasing landlessness among poorer traditional land owners and inequality in land ownership is tantamount to insignificant under this act. Moreover, the Pearson chi-square value of 0.058 at $5 \%$ significance level showed that incorporating the land use act in the constitution does not make amendment difficult and

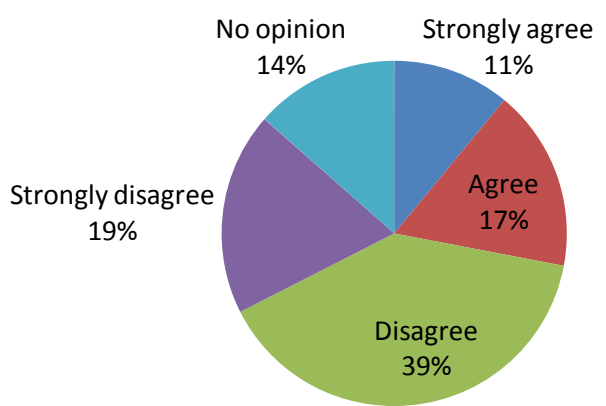

Figure 4: A Pie Chart showing the Percentage of Respondence on if the Land Use Act Represents Compulsory Acquisition of Citizen Property or Naturalization of Land by the Ruling Elite without Compensation to Land Owners. 
Citation: Opafunso ZO, Bruno-Imokhai JO, Akinbosade BA (2015) Effects of the 1978 Land Use Act on Sustainable Mining and Petroleum Industries in Nigeria. Arts Social Sci J 6: 106. doi:10.4172/2151-6200.1000106

Page 5 of 5

should not remain statutory enactment outside the constitution. The paper recommended the following categorically to the government of the country; The right sense of justice and fairness to be played by the government in terms of land use administration to greatly reduce further allegations and critics by Nigerians in terms of this act enriching government officers, to allow for reduced unrest and incessant kidnapping of in petroleum workers in the Niger-Delta, the government should allow land owners determine the value of the land through negotiations with the government. According to Nozick, to eliminate conflict from land issues, his theory points out the need for negotiations to be made between the government and individuals for acquisition of land, to stabilize and regulate the prices of land in areas of the country, the government should give a suitable mechanism in the land use act in order to address this issue, there's need for the enactment of an appreciable legislation that would provide effective legal support for assessment of a fair and just compensation fee for environmental damage in the Niger-delta, in terms of land acquisition for their operations, it is important for these industries to involve the government and not traditional rulers in the community. In this way, security is assured eliminating problems that may arise from masses in the community and for the land use act to flourish and to create an environment for mining and petroleum industries, there is need for fundamental rethinking of land use control mechanism, policy and action.

\section{References}

1. Razak SE (2011) The Land Use Act of 1978. Appraisal, Problems and Prospects 5-55.

2. Public land decree (1976) Public Land Decree No 23. Laws of the Federation of Nigeria, 1990 (Edn,): 24-26.

3. Ojigi ML (2012) Geospatial Mapping for Crime Indexing and Monitoring in Minna and Environs, Niger State of Nigeria. Nigerian Journal of Surveying and Geoinformatics 2: 83-100.

4. Oseni WT (2011) Doctrine of Equity and Statutes in Nigeria ( $2^{\text {nd }}$ edn) $55-58$.

5. Bolaji WA (2011) Nigerian land system. 34-37.

6. Adegboye RO (1967) The Need for Land Reform in Nigeria. J Eeon Soc Studies Niger 9: 339-350.

7. Udo RK (1985) The Land Use Decree 1978 and its antecedents. University Lectures, University of Ibadan 44-46.

8. Famoriyo SE (1972) Land Tenure and Agricultural Development in Nigeria Nigerian Institute of Social and Economic Research, Ibadan 14-20.

9. Omotola JA (1985) Essays on the Land Use Act. 1978. Lagos University Press, Lagos 4-5

10. Land Use Act (1978) Federal Republic of Nigeria Official Gazette. No.14 Federal Ministry of Information, Printing Division, Lagos, Nigeria 65: 2-6

11. Nozick R (1974) Anarchy, State and Utopia. Blackwell, New York 39-41.

12. Locke J (1688) Two Treaties of Government and Revolution 557. 